\section{IN SILICO ANALYSIS AND FUNCTIONAL CHARACTERIZATION OF FHUB, A COMPONENT OF ERWINIA MALLOTIVORA FERRIC HYDROXAMATE UPTAKE SYSTEM}

Nor Mustaiqazah Juria, Aimera Farhana Samsuddina,b, Abdul Munir Abd Muradb, Amin Asyraf Tamizia, Mohd Azhar Hassanc, Norliza Abu Bakara*

aBiotechnology \& Nanotechnology Research Centre, Malaysian Agricultural Research \& Development Institute, 43400 MARDI Head Quarter Serdang, Selangor, Malaysia

bSchool of Bioscience and Biotechnology, Faculty of Science and Technology, Universiti Kebangsaan Malaysia, 43600 UKM Bangi, Selangor Darul Ehsan, Malaysia

cHorticulture Research Centre, Malaysian Agricultural Research \& Development Institute, 43400 MARDI Head Quarter Serdang, Selangor, Malaysia
Article history

Received

30 January 2020

Received in revised form

12 March 2020

Accepted

17 March 2020

Published online

28 April 2020

*Corresponding author lizaab@mardi.gov.my

\section{Graphical abstract}

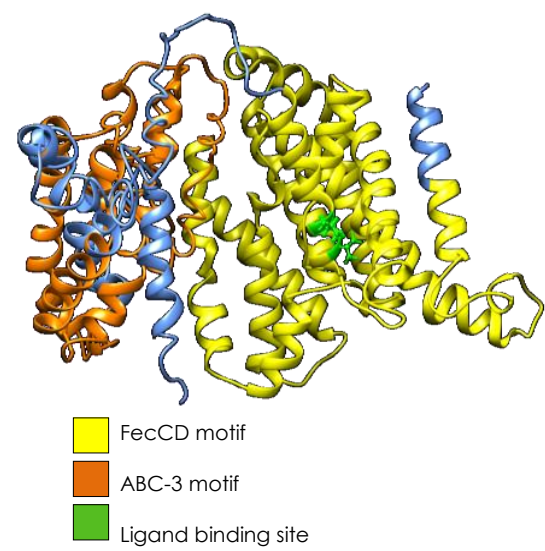

\begin{abstract}
Iron is a critical element for bacterial growth as most pathogenic bacteria relies on their host for iron supply. However, iron sources are bounded to the host iron binding protein and specific iron acquisition mechanism is required to chelate and transport the iron to the bacteria. Ferric hydroxamate uptake system or fhu is one of the transport systems that import iron in the form of ferric hydroxamate/ ferrichrome from the extracellular environment into the bacterial cytosol. In this present study, a detailed in silico structural analysis was conducted on an important component of fhu transport member from Erwinia mallotivora named as fhuB. This provide us the structural properties of the protein which includes the domain and 3D model, phylogenetic analysis and the membrane topology. For functional analysis, a knockout mutant of fhuB gene strain was generated to evaluate the effect of silencing this gene during $E$. mallotivora infection in papaya. When compared to the wild $E$. mallotivora strain, fhuB mutant strain of $E$. mallotivora loss its virulence in causing dieback disease symptom in papaya. The result of this study has revealed the significant role of iron acquisition and metabolism during E. mallotivora pathogenesis. This highlights fhuB role and importance as the target gene; to inhibit iron uptake in E. mallotivora for future study and as a part of future consideration for dieback disease management strategy in papaya.
\end{abstract}

Keywords: Dieback disease, Erwinia mallotivora, fhuB, papaya, iron uptake

\begin{abstract}
Abstrak
Ferum merupakan elemen penting bagi pertumbuhan bakteria kerana kebanyakan bakteria patogen bergantung pada perumah untuk mendapatkan bekalan ferum mereka. Walau bagaimanapun, sumber ferum terikat kepada
\end{abstract}


protein pengikat ferum perumah. Mekanisme pengambilalihan ferum diperlukan untuk mengkelat dan mengangkut ferum ke dalam pathogen. Sistem pengambilan hidroksamat ferum atau dikenali sebagai fhu adalah salah satu sistem pengangkutan yang mengimport ferum dalam bentuk ferik hidroksamat/ ferikrom dari persekitaran ekstrasel ke dalam sitosol bakteria. Dalam kajian ini, analisis struktur in silico yang terperinci telah dijalankan ke atas komponen penting sistem pengangkutan fhu E. mallotivora yang dinamakan sebagai fhuB. Ini bertujuan untuk mengetahui gambaran struktur protein dan merangkumi domain dan model 3D, analisis filogenetik dan analisis topologi membran. Untuk analisis kefungsian, satu mutan fhuB E. mallotivora dihasilkan untuk menilai kesan gen ini terhadap kepatogenan E. mallotivora semasa menyerang pokok betik. Apabila dibandingkan dengan E. mallotivora liar, mutan fhuB E. mallotivora kehilangan kevirulenannya untuk menyebabkan simptom penyakit mati rosot pada pokok betik. Hasil kajian ini menunjukkan peranan penting proses pengambilan dan metabolisma ferum sebagai salah satu mekanisme kepatogenan E. mallotivora. la juga menunjukkan peranan fhuB sebagai salah satu gen sasaran yang boleh digunakan untuk menghalang pengambilan ferum oleh E. mallotivora, justeru mengetengahkannya sebagai salah satu strategi pengurusan penyakit mati rosot bagi betik di masa hadapan.

Kata kunci: Penyakit mati rosot, Erwinia mallotivora, fhuB, betik, pengambilan ferum

(C) 2020 Penerbit UTM Press. All rights reserved

\subsection{INTRODUCTION}

Dieback disease in papaya due to E. mallotivora infection caused significant loss in papaya production in Malaysia [1]. Similar to other pathogenic bacteria, iron is a crucial nutrients source for E. mallotivora. Erwinia mallotivora genome sequences has already been obtained via Next generation sequencing. It was reported that $2 \%$ of $E$. mallotivora genome were accounted for iron acquisition and metabolism [2], suggesting the significant contribution of this mineral for the growth of E. mallotivora. In other reported virulence repertoire of pathogens genomic data, iron acquisition was identified as a key virulence determinant gene for classification of pathogenic bacteria strain [3]. Proteomic study conducted for $E$. mallotivora also highlighted the significant roles of iron transport as part of the bacteria pathogenesis mechanism [4].

Iron is an essential metal for most prokaryotes and eukaryotes due to its utilisation by the organism during redox processes. This enable the organism to participate in many electron transfer reactions [5]. It serves as the key element for various critical metabolic process in organisms such as generation of energy in Tricarboxylic Acid Cycle (TCA)/ Kreb cycle, photosynthesis, synthesis of DNA and for defence against reactive oxygen species (ROS). Even so, supply of iron is a problem, especially for aerobic bacteria [6]. Depending on the environment condition, iron can exist in different form. In anaerobic and low $\mathrm{pH}(<3)$, iron exist in the soluble form which can be easily taken up by the bacteria without the assistance of chelating agents like siderophores. However, in aerobic and higher $\mathrm{pH}$ (neutral and alkaline condition) environment, irons in $\mathrm{Fe}^{3+}$ form are precipitated to form insoluble compounds and thus not readily available [7]. As a part of plant defence against invasion, iron is sequestered by the plant host binding proteins to make it inaccessible for any pathogen. However, successful pathogens were able to overcome and cope with the ion limitation/constraint through their sequestering strategies [8]. Depending on their structure, there are three major types of siderophore; hydroxamates, catecholates and ahydroxycarboxylates. Each type of siderophores is required and is fitted with specific membrane transport system for them to be transported into the cytosol [9].

One of the important iron binding and uptake system consist of the ferric hydroxamate uptake (Fhu) system which is involved in the uptake of ferric hydroxamate type of siderophores [10]. The Fhu system is composed of four genes namely fhUA, fhuC, fhUD and fhuB whereby FhUA receptor transports ferrichrome-iron across the outer membrane, whilst periplasmic FhUD and cytoplasmic membrane FhUB transport ferrichrome and other ferric hydroxamates from the periplasm across the cytoplasmic membrane into the cytoplasm [11].

Structurally, fhu membrane transport family are made up of 3 components; a binding protein (BP) located in the periplasm, integral membrane protein (IMP) that is embedded within the cytoplasmic membrane and two nucleotide binding domain (NBD) that are located in the cytoplasm [11, 12]. The IMP which is embedded in the cytoplasm plays an important role in the design and the functionality of 
fhu importers. The IMP not only interact with the molecules to be imported into the cytosol, but also with other transport components of the system, where they have binding site for BP (FhuD) and NBD (FhuC) $[13,14]$. This factor might contributes to the selection of this component (IMP) as the target for gene knockout or gene silencing for functional study of this transport system family, as well as to effectively hinder the intake of iron into the system. Interestingly, FhuB was shown to be important for virulence activity of several pathogenic bacteria [15].

In our previous study, FhuB protein was found to be up-regulated in media cultures of E. mallotivora that stimulated the expression of pathogenicity (hrp) and virulence proteins of the pathogen in vitro [4]. Giving its importance, a research was initiated to further characterize the fhuB gene from E. mallotivora. This research involved in silico characterization and functional analysis of one of the virulence gene of E.mallotivora, as an effort to identify target genes to be used in future strategy to combat papaya dieback disease.

\subsection{METHODOLOGY}

\subsection{Retrieval of EmfhuB and Related Sequences}

The amino amino acid sequence of EmfhuB was retrieved from NCBI database (http://www.ncbi.nlm.nih.gov) and was downloaded in FASTA format for the in silico analysis. The homologous sequences of EmfhuB were identified by BLASTp tools in NCBI non-redundant sequence database (http://www.ncbi.nlm.nih.gov/).

\subsection{Phylogenic Tree Construction}

The phylogeny tree was constructed by MEGA Version 7.0 via Neighbor Joining (NJ) method, with $p$ distance as substitution model via Maximum Parsimony (MP) methods.

\subsection{Domain and Protein 3D Model Prediction}

Motif finder server (http://www.genome.jp/tools/motif/) was used to identify the protein domain. The 3D structure of EmfhuB was predicted via SWISS-Model Workspace (https://swissmodel.expasy.org/) by selecting the most suited template. The quality of the predicted structure was determined by QMEAN program in the ExPASy server of SWISS-Model Workspace.

\subsection{Subcellular Localization and Transmembrane Topology Prediction}

Subcellular localization of EmfhuB was predicted with TBpred [16] and Gneg-mPLoc [17] server. Meanwhile, the Phobius server (http://phobius.sbc.su.se/) was used to predict the presence $\mathrm{N}$-terminal signal peptides and identification of transmembrane helices of EmfhuB.

\subsection{Generation of Knockout Mutant ( $\triangle E$ EmfhuB) of Erwinia mallotivora}

A fhuB gene knockout mutant of $E$. mallotivora $(\triangle E m f h \cup B)$ was constructed using the TargeTron Knockout system to validate the importance of fhuB during the pathogenesis. A combination of genespecific and intron-specific primers named IBS, EBS Id, and EBS2 that were used to synthesize PCR fragments for the generation of functional cassettes was designed using the Sigma-Aldrich computer-based TargeTron algorithm design site (http://www.sigmagenosys.com/targetron/). The primers shown below were synthesized by First Base (Malaysia).

Table 1 Primers for $\triangle E m f h u B$ splicing by overlap $P C R$ reaction

IBS1/2 AAAAAAGCTTATAATTATCCTTACACTGCGGGCCAGTGCGCCCAGATAGGGTG

EBS1/delta CAGATTGTACAAATGTGGTGATAACAGATAAGTCGGGCCACCTAACTTACCTTTCTTTGT

EBS2 TGAACGCAAGTTTCTAATTTCGGTTCAGTGTCGATAGAGGAAAGTGTCT

The PCR product was treated with Xhol (New England Biolabs, Beverly, MA, USA) and BsrGl (New England Biolabs) restriction enzymes and ligated into the PACD4K-C linear vector digested with the same enzymes. For amplification and validation purposes, ligated products were transformed into E.coli DH5a strain. Transformants were selected on LB agar plates containing $50 \mu \mathrm{g} / \mathrm{ml}$ kanamycin, and the plasmid DNAs were purified using Qiagen columns. Selection of potential target site and generation of $\triangle E m f h \cup B$ functional cassettes for targeted gene disruption and splicing by overlap extension PCR were carried out using $P C R$ and sequencing analysis before the generation of the targeted $\triangle E$ EmfhUB in E.mallotivora.

Erwinia mallotivora competent cells for electropration were generated based on modified method by Grosser \& Richardson (2016). To generate a $\triangle E m f h u B$ strain, the $E$. mallotivora was cultured at $28^{\circ} \mathrm{C}$ until the culture reached an optical density at $600 \mathrm{~nm}$ of approximately 1.0. Bacteria harvested by centrifugation at $12,000 \mathrm{~g}$ for $2 \mathrm{~min}$ were washed three times with $0.5 \mathrm{M}$ sucrose and then suspended in $0.5 \mathrm{M}$ sucrose. One microgram of the pAR 1219 and the plsmid construct for $\triangle E m f h \cup B$ were electroporated into E. mallotivora cells using a BioRad micropulser (Bio-Rad) at $2.5 \mathrm{kV}$. The transformed bacteria were rescued then cultured on LB agar plates containing kanamycin at $30^{\circ} \mathrm{C}$.

2.6 Plant Materials, Bacterial Inoculation and Scoring

The 4-months old seedlings of Carica papaya (Eksotika I) were supplied by the Malaysian 
Agricultural Research and Development Institute (MARDI) Pontian, Johor. The seedlings were grown in a greenhouse, where they received $13 \mathrm{~h}$ of light a day $\left(30^{\circ} \mathrm{C}\right)$. The wild and knockout mutant ( $\left.\triangle E m f h \cup B\right)$ of $E$. mallotivora strains were cultured in LB broth and were left to grow at $28^{\circ} \mathrm{C}$ incubator shaker until reaching $\mathrm{OD}_{600}$ of 1 . About $5 \mathrm{~mL}$ of $E$. mallotivora culture was injected into the stem of all seedlings at around $15 \mathrm{~cm}$ from the shoot area. The scoring was made started from day 3 up to day 30 of post inoculation (dpi).

\subsection{Disease Index and Statistical Analysis}

Disease severity was evaluated using 5 -stage scale; 0 = symtompless, 1 = leaf vein blackening, 2 = leaf vein blackening + slightly wilting, 3 = leaf stalk wilting, $4=$ stem blackening and 5 = plant died. The disease severity index (DSI) was computed following the previous study [4]. The experiments were repeated thrice, and the data were analyzed for significant differences via SPSS Statistics 17.0 software (SPSS, Chicago, IL, USA).

\subsection{RESULTS AND DISCUSSION}

\subsection{EmfhuB Related Sequences and Phylogenetic Analysis}

The ORF of fhuB CDNA sequence obtained from the draft genome of Erwinia mallotivora BT-MARDI [2] consist of 640 amino acid nucleotides. The BLASTP homology search in the Genbank non-redundant databases had revealed a total of 40 related amino acid sequences (>50\% identity), which hit majorly under enterobacteria and g-proteobacteria species. This group of proteins belongs to PRK10577 superfamily that contains the motif of dimer interface, ABC-ATPase subunit interface and putative penicillin-binding protein (PBP) binding regions.

Erwinia mallotivora fhuB (EmfhuB) protein sequence showed the highest identity with $f$ u $B$ of Pantoea coffeiphila and Erwinia sp. JUb26 (91\%), and 79-78\% identity with other bacteria families including Pantoea rodasii, Enterobacter cancerogenus, Plautia stali and Pantoea rwandensis. However, low identity percentage showed with three Erwinia species including Erwinia billingiae (57\%), Erwinia sp. Leaf53 (60\%) and Erwinia sp. B116 (60\%) suggested low conservation of fhuB at genus level. No other hits from other Erwinia species were shown.

Identification of EmfhuB homologous sequences (descended from a common ancestor) is important for a reliable evolutionary analysis [18]. A total of 20 EmfhuB homologous protein sequence (identity $>50 \%$ ) was used to construct the tree (Figure 1). The branching pattern of the tree showed that EmfhuB were well-clustered into three major groups. This branching pattern was supported by high percentage of bootsrap values (>70\%) on each node of the major branch. Group 1 and 2 were mainly made up of enterobacteria species, whereas group 3 was made up of g-proteobacteria species. This suggest the high conservation of $f$ u $B$ protein sequence within the bacteria family. EmfhuB was located under group 2 which was highly closely related to Pantoea coffeiphila and Erwinia sp. JUb26, with bootstrap value of $100 \%$.

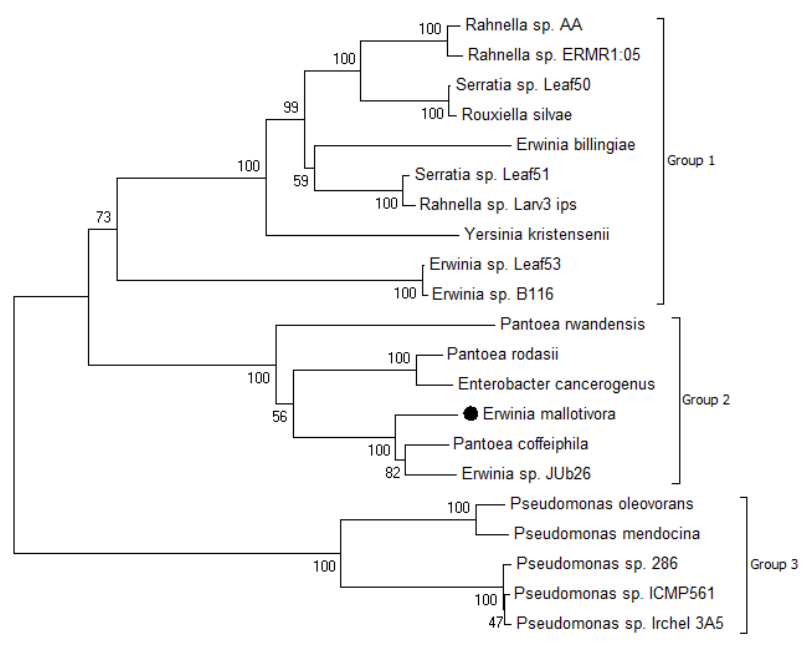

Figure 1 Phylogenetic tree of homologous amino acid sequence of EmfhuB

\subsection{Domain and 3D Structure}

Two transport family motifs, named as FecCD and $A B C-3$ were detected on EmfhuB protein sequence (Figure 2). FecCD motifs were identified in two locations, first which was located near the N-terminal from residue 11 up to 313 and the second at residues 408 up to residue 610, near the C-terminal. The ABC-3 motif spanned from residue 408 to residue 601 .

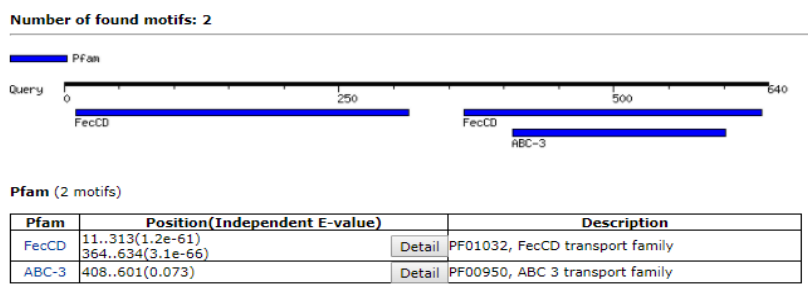

Figure 2 Two functional motifs for the fhuB protein of $E$. mallotivora

Homology 3D modelling prediction of EmfhuB via swiss-model (Figure 3) disclosed that EmfhuB showed the highest identity with 2 chain (Chain A and B) of $E$. coli Vitamin $B 12$ import system permease protein BtuC (PDB ID: 4 r9u.1.A, X-ray, $2.79 \AA$ resolution). The gene was used as the template for homology modelling. The chain A span from the beginning of $\mathrm{N}$ terminal to residue 314 of EmfhuB with $33.70 \%$ (GMQE of 0.34 , QMEAN of -2.72 ) identity, whereas the chain 
B span from residue 340 to the end of $C$-terminal with identity of $28.04 \%$ (QMQE of 0.35 , QMEAN of -3.55 ). QMEAN [19] estimates the combination of different geometrical properties and provides global (entire structure) and local (per residue) absolute quality of the predicted 3D structure on the basis of single model. Scores of $\geq-4.0$ are an indication of models with high quality, which was also highlighted by "thumbs-up" symbol, as shown in Figure 3. This suggests both templates are suitable for EmfhuB 3D structure prediction.
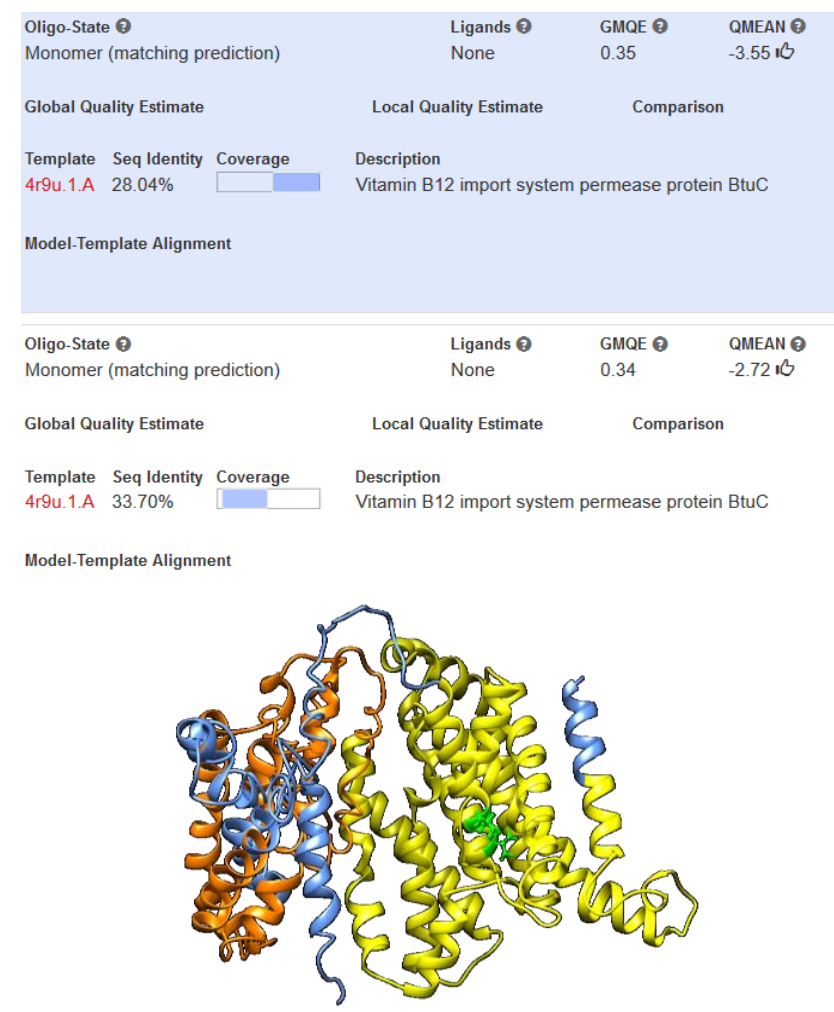

Figure $33 \mathrm{D}$ model prediction of EmfhuB. The ligand binding site is labeled with green color while the yellow color is the FecCD motif. The orange color is the $A B C-3$ motif

\subsection{Signal Peptide, Secretion System and Transmembrane Analysis}

The results indicated that EmfhuB is localized as an integral membrane protein, specifically at the cell inner membrane (cytoplasmic membrane) of $E$. mallotivora. Via Phobuis, it was revealed that $\mathrm{N}$ terminal signal peptides and transmembrane helices were presence in the EmfhuB sequence, spanning from nucleotide 1 to 19 (Figure 4). A signal peptide which is a short leader sequence (normally 16-30 amino acids long) are located at the $\mathrm{N}$-terminus of the newly synthesized protein.

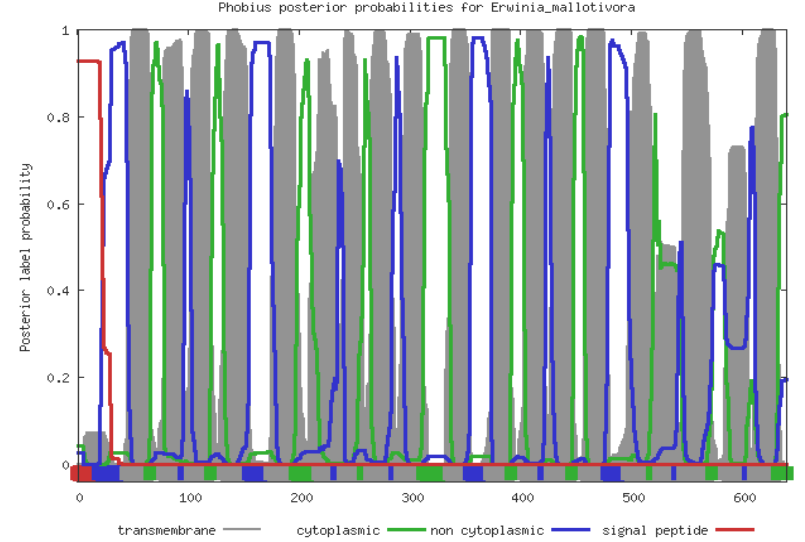

Figure 4 Prediction of the presence of transmembrane domains and signal peptides via Phobius server. The $\mathrm{x}$-axis shows the number of the amino acids of the specific EmfhuB sequences

\subsection{Transmembrane Topology of EmfhuB}

The prediction of membrane topology provides the most probable location on where the soluble domains are oriented relative to the plane of the membrane. This offers guidance for further experiments to identify functional domains of membrane proteins.

Cytoplasmic transmembrane arrangement showed that EmfhuB contains 16 a-helix transmembrane region which is also known as hydrophobic region (8 at each halves of $\mathrm{N}$ - and $\mathrm{C}$ termini) which are connected by 7 positively charged loops facing the cytosol (cytoplasmic region) and 8 loops facing the periplasm (noncytoplasmic region). Both the $\mathrm{N}$ - and $\mathrm{C}$-terminal end were facing the cytosol (Figure 5). The loop regions that are exposed to the periplasm and cytosol are suggested as the putative interaction site of fhuB with the periplasmic binding protein (FhUD) and ATPhydrolase binding protein $(F h \cup C)$, respectively. Compared to the well-studied/model fhuB of E.coli, EmfhuB consist of 20 transmembrane regions (10 at each halves).

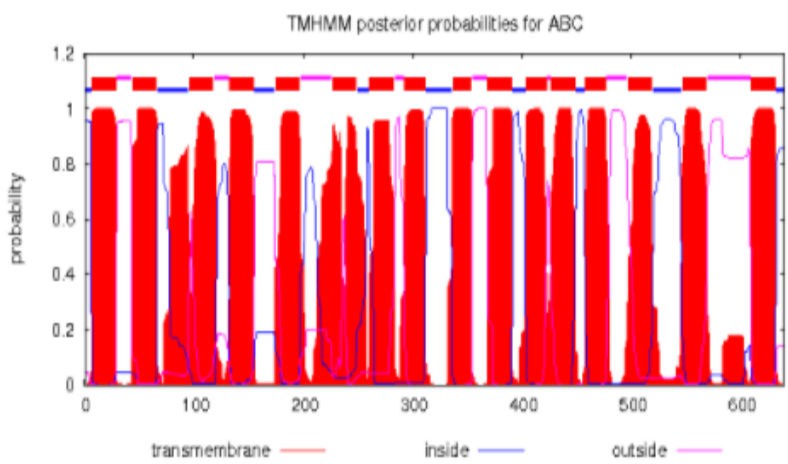

Figure 5 Predicted topology of EmfhuB protein 


\subsection{Construction and Molecular Validation of $\triangle E m f h u B$ Strain}

Construction and molecular validation of $\triangle E m f h u B$ were carried out using Targetron Gene Knockout System. Identification of binding LItr group II intron site within the EmfhuB gene sequence for the generation of mutated PCR products were carried out using the algorithm located at Sigma Aldrich targetron website (www.sigmaaldrich.com/targetron). Primers identified from the analysis were synthesized and used to generate PCR fragment in a splicing by overlap PCR reaction. Generation of EmfhuB functional cassettes for targeted gene disruption and splicing by overlap extension PCR were carried out as shown in Figure 6. The PCR utilizing the primers in Table 1 to mutate intron at several positions generated a PCR fragment of $350 \mathrm{bp}$ in size with Hindlll and BsrGI restriction enzymes at the 5' and 3' UTR region. Plasmids containing the targeted fragments were amplified and digested with Hindll and $B s r G I$ restriction enzymes and sub cloned into the PACD4K-C linear vector to generate construct for the targeted $\triangle E m f h \cup B$.

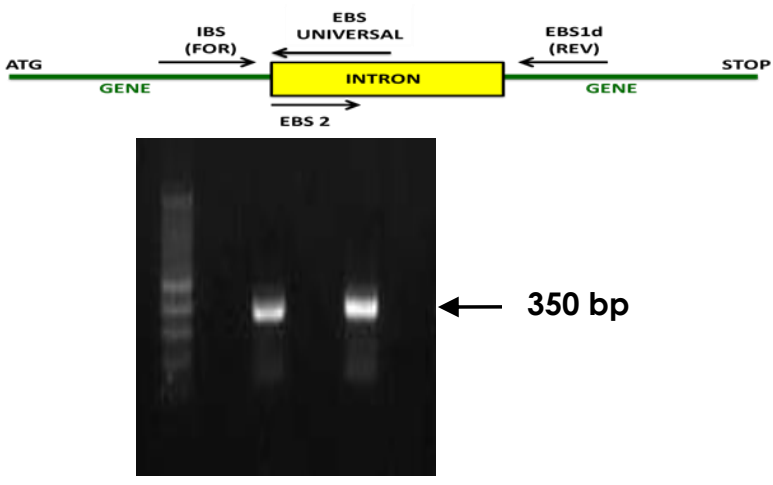

Figure 6 Schematic presentations and PCR analysis carried out for the generation of EmfhuB splicing and overlapped $P C R$ products for the generation of $\triangle E m f h \cup B$ mutants

TargeTron system plasmids require the use of $\mathrm{T7}$ promoter for targeting and mutation of selected genes into the genome of the bacteria of interest. Since E. mallotivora does not expressed T7 RNA polymerase, pAR 1219, a pBR322-based vector that expresses T7 RNA Polymerase under the control of the IPTG inducible lac UV5 promoter was used during the TargeTron Gene Knockout activity. Transformation of the plasmid PAR 1219 was carried out to obtain the T7 promoter that can be used to express the intron and to disrupt the chromosomal genes in E. mallotivora. Erwinia mallotivora-pAR1219 strains were succesfully transformed with the effectors functional cassette for the gene via electroporation and chemically competent cells transformations. Postive transformants with mutations which were introduced in EmfhuB were detectable after 48 hours selection on kanamycin plates. Intron insertions were detected by PCRs with genomic DNA isolated from the transformed colonies by using combinations of gene specific and intron-specific primers for verification. The positive transformants were later verified by DNA sequencing. Confirmation of the $\triangle E m f h u B$ mutants were also conducted via PCR colony performed using specific primers targeting E. mallotivora $\mathrm{HrpN}$, Isochorismate mutase and Hrps genes of as shown in Figure 7. This is to further confirm that the targeted knockout was carried out in E. mallotivora strain.

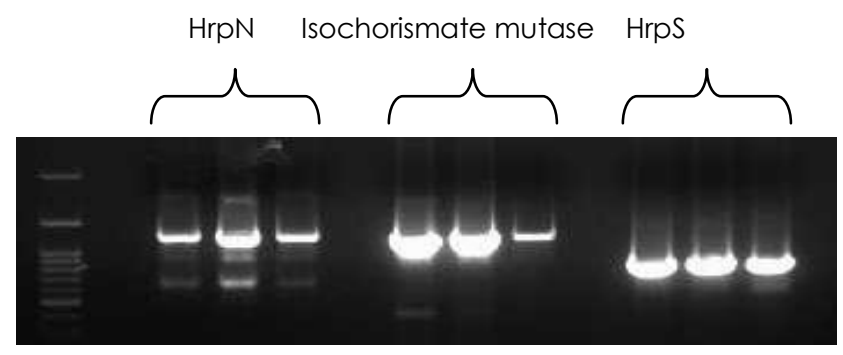

Figure 7 Analysis of $E$. mallotivora mutants using $E$. mallotivora mutants pecific primers to confirmed the targeted mutation were carried out in E. mallotivora strains. Three specific primers that corresponded to HrpN, Isochorismate mutase and HrpS E. mallotivora were used to confirm that the $\triangle E m f h \cup B$ mutants were targeted in $E$. mallotivora strains

\subsection{Involvement of fhuB in the Pathogenicity $E$. mallotivora}

EmfhuB deletion mutant of $E$. mallotivora ( $\triangle E m f h \cup B$ ) was successfully generated via Targetron Gene Knockout System. To evaluate the contribution of fhuB in E. mallotivora pathogenicity, wild-type and $\triangle E m f h u B$ E. mallotivora strain was inoculated to papaya seedlings. The scoring on the progression of dieback disease severity index on papaya seedlings (Table 2) showed that the stage 1 disease symptom (blackening of leaf vein) was detected as early as 3 days post infection (dpi) in plants inoculated with wild-type E. mallotivora. The progression of disease continued until $20 \mathrm{dpi}$, where at this stage the plants completely died. In contrast, no disease symptoms were detected in plants inoculated with $\triangle E m f h \cup B$ (scoring was made up to $30 \mathrm{dpi}$ ). This result suggested the importance of fhuB for $E$. mallotivora pathogenicity. Knockout mutation of this gene might leads to iron deprivation that eliminates the virulence of E. mallotivora.

However, besides fhu transport system, the presence of other iron transport systems including Btu (Vitamin 12 uptake system), Feo and efe (Ferrous iron transport system) were also identified in the $E$. mallotivora genomic data [2]. This has raised a question on how a knockout of a gene in one of the iron transport system could lead to the complete loss in the virulence of E. mallotivora. At this point, our result suggest that the ferric-hydroxamate system might be the sole or major source of iron for $E$. mallotivora. To confirm this, further experiment on the growth of mutated EmfhuB strain in various sources of 
iron-restricted media could be conducted. This is in accordance to a report by Speziali et al. 2006 for the bacteria S. aureus [20]. The deletion of fhuB had resulted in the inability to transport or utilize any form of ferric-hydroxamate complexes including ferrichrome, Desferal, coprogen and aerobaction [20]. In another report, mutation of fhu operon for Yersinia pestis resulted in deficient uptake of ion [9].

Table 2 The dieback disease severity scoring in papaya seedlings inoculated with wild and fhuB knockout mutant $E$. mallotivora. (Stage $0=$ symtompless, Stage $1=$ leaf vein blackening, Stage 2 = leaf vein blackening + slightly wilting, Stage 3 = leaf stalk wilting, Stage $4=$ stem blackening and Stage 5 = plant died)

\begin{tabular}{llllllll}
\hline $\begin{array}{l}\text { Strain of } \\
\begin{array}{l}\text { Erwinia } \\
\text { mallotivora }\end{array}\end{array}$ & $\begin{array}{l}\text { Day- } \\
\mathbf{3}\end{array}$ & $\begin{array}{l}\text { Day- } \\
\mathbf{6}\end{array}$ & $\begin{array}{l}\text { Day- } \\
\mathbf{9}\end{array}$ & $\begin{array}{l}\text { Day- } \\
\mathbf{1 2}\end{array}$ & $\begin{array}{l}\text { Day- } \\
\mathbf{1 6}\end{array}$ & $\begin{array}{l}\text { Day- } \\
\mathbf{2 0}\end{array}$ & $\begin{array}{l}\text { Day- } \\
\mathbf{3 0}\end{array}$ \\
\hline $\begin{array}{l}\text { Wild type } \\
\text { Knockout } \\
\text { mutant } \\
(\Delta \text { EmfhuB })\end{array}$ & 1 & 2 & 2 & 3 & 4 & 5 & 5 \\
\hline
\end{tabular}

\subsection{CONCLUSION}

In this study, we have identified in silico structural properties of fhuB proteins as well as its critical role in affecting the virulence of E. mallotivora. It these studies, fhuB genes was characterized using bioinformatic tools and was shown to contain all element of fhuB motif. $\triangle E m f h \cup B$ was successfully generated via Targetron system and the effect of knockout strain was observed through plant screening method using plant infection assay. The outcomes of this project will have important implications in defining the pathogenesis of $E$. mallotivora.

\section{Acknowledgement}

This study was supported partly by FRGS Fund Grant FRGS/1/2015/STO3/MOA/02/1 from MOHE and MARDI Pembangunan PRB405 research grant.

\section{References}

[1] Chan, Y. K., and Baharuddin, A. G. 2010. Rejuvenating the Flagging Papaya Industry in Malaysia: The Role of MAFC. Acta Hortic. 851: 37-40. DOI: 10.17660/ActaHortic.2010.851.2

[2] Redzuan, R. A., N. Abu Bakar, L. Rozano, R. Badrun, N. Mat Amin, and M. F. Mohd Raih. 2014. Draft Genome Sequence of Erwinia mallotivora BT-MARDI, Causative Agent of Papaya Dieback Disease. Genome Announc. 2(3): e00375-14. DOI:10.1 128/genomeA.00375-14.

[3] Chander, A. M., R. Kochhar, D. K. Dhawan, S. K. Bhadada, and S. Mayilraj. 2018. Genome Sequence and Comparative Genomic Analysis of a Clinically Important Strain CD1 1-4 of Janibacter melonis Isolated from Celiac Disease Patient. Gut pathogens. 10: 2. DOl: 10.1186/s13099-018-0229-x.
[4] Abu Bakar, N., R. Badrun, L. Rozano, L. Ahmad, M. F. Mohd Raih, and A. A. Tarmizi. 2017. Identification and Validation of Putative Erwinia mallotivora Effectors via Quantitative Proteomics and Real Time Analysis. J. Agric. Food. Tech. 7(9): 10-21.

[5] LU, Y., L. Xu, W. Shu, J. Zhou, X. Chen, Y. Xu, and G. Qian. 2017. Microbial Mediated Iron Redox Cycling in $\mathrm{Fe}$ (hydr)oxides for Nitrite Removal. Bioresour Technol. 224: 34-40. DOI: 10.1016/j.biortech.2016.10.025

[6] Alhasawi, A, J. Costanzi, C. Auger, N. D. Appanna, and V. D. Appanna. 2015. Metabolic Reconfigurations Aimed at the Detoxification of a Multi-Mmetal Stress in Pseudomonas Fluorescens: Implications for the Bioremediation of Metal Pollutants. J Biotechnol. 200: 3843. DOI: 10.1016/j.jbiotec.2015.01.029.

[7] Munzinger, M., H. Budzikiewicz, D. Expert, C. Enard, and J. Meyer. 2000. Achromobactin, a New Citrate Siderophore of Erwinia chrysanthemi. A Journal of Biosciences. $\quad 55$ : 328-332. DOI: https://doi.org/10.1515/znc-2000-5-605

[8] Aznar, A., and A. Dellagi. 2015. New Insights into the Role of Siderophores as Triggers of Plant Immunity: What Can We Learn from Animals? J Exp Bot. 66(1 1): 3001-10. DOI: 10.1093/jxb/erv155.

[9] Forman, S., M. J. Nagiec, J. Abney, R. D. Perry, and J. D. Fetherston. 2007. Analysis of the Aerobactin and Ferric Hydroxamate Uptake Systems of Yersinia pestis. Microbiology. 153(7): 2332-41. DOI: 10.1099/mic.0.2006/004275-0.

[10] Hantke, K. 2004. Ferrous Iron Transport. Iron Transport in Bacteria. 178-184. Edited by J. H. Crosa, A. R. Mey \& S. M. Payne. Washington, DC: ASM Press. DOI: 10.1093/femsre/fuv049.

[11] del Rio, M. L., J. Navas, A. J. Martin, C. B. Gutierrez, J. I. Rodriguez-Barbosa, and E. F. Rodriguez Ferri. 2006 Molecular Characterization of Haemophilus parasuis Ferric Hydroxamate Uptake (fhu) Genes and Constitutive Expression of the FhuA Receptor. Vet. Res. 37: 49-59. DOI: 10.1051/vetres:2005039.

[12] Fecker, L. and V. Braun. 1983. Cloning and Expression of the fhu Genes Involved in Iron (III)-hydroxamate Uptake by Escherichia coli. J. Bacteriol. 156: 1301-1314.

[13] Abdelhamed, H., J. Lu, A. Shaheen, A. Abbass, M. L. Lawrence, and A. Karsi. 2013. Construction and Evaluation of an Edwardsiella ictaluri fhuC Mutant. Vet Microbiol. 162(2-4): 858-65. DOI: 10.1016/j.vetmic.2012.11.006.

[14] Mikael, L. G., P. D. Pawelek, J. Labrie, M. Sirois, J. W. Coulton, and M. Jacques. 2002. Molecular Cloning and Characterization of the Ferric Hydroxamate Uptake (fhu) Operon in Actinobacillus pleuropneumoniae. Microbiology. 148(9): 2869-82. DOI: 10.1099/00221287148-9-2869.

[15] Abdelhamed, H, J. LU, M. L. Lawrence, and A. Karsi. 2016. Ferric Hydroxamate Uptake System Contributes to Edwardsiella ictaluri Virulence. Microb Pathog. 100: 195200. DOI: 10.1016/j.micpath.2016.09.018.

[16] Rashid, M., S. Saha and G. P. S. Raghava. 2007. Support Vector Machine-based Method for Predicting Subcellular Localization of Mycobacterial Proteins Using Evolutionary Information and Motifs. BMC Bioinformantics. 8: 337. DOI: 10.1 186/1471-2105-8-337.

[17] Shen, H. B. and K. C. Chou. 2010. Gneg-mPLoc: A Topdown Strategy to Enhance the Quality of Predicting Subcellular Localization of Gram-negative Bacterial Proteins. Journal of Theoretical Biology. 264: 326-333. DOI: 10.1016/j.jtbi.2010.01.018.

[18] Hall, B.G. 2013. Building Phylogenetic Trees from Molecular Data with MEGA. Molecular Biology and Evolution. 30(5): 1229-1235. DOI: 10.1093/molbev/mst012.

[19] Benkert, P., M. Biasini, and T. Schwede. 2011. Toward the Estimation of the Absolute Quality of Individual Protein Structure Models. Bioinformatics. 27: 343-350. DOI: 10.1093/bioinformatics/btq662. 
[20] Speziali, C. D., S. E. Dale, J. A. Henderson, E. D. Vinés, and D. E. Heinrichs. 2006. Requirement of Staphylococcus aureus ATP-Binding Cassette-ATPase FhuC for Iron-Restricted Growth and Evidence that it
Functions with More than One Iron Transporter. Journal of Bacteriology. 188(6): 2048-2055. DOI: 10.1128/JB.188.6.2048-2055.2006. 